\title{
Partial hydatidiform mole evolving into metastatic trophoblastic tumor: case report
}

\author{
I. Elamouri*, S. Tanouti, H. Taheri, H. Saadi, A. Mimouni
}

Department of Obstetrics and Gynecology, Mohammed VI University Hospital Center, Oujda, Morroco

Received: 09 February 2020

Accepted: 03 March 2020

*Correspondence:

Dr. I. Elamouri,

E-mail: imane.elamouri@gmail.com

Copyright: (c) the author(s), publisher and licensee Medip Academy. This is an open-access article distributed under the terms of the Creative Commons Attribution Non-Commercial License, which permits unrestricted non-commercial use, distribution, and reproduction in any medium, provided the original work is properly cited.

\begin{abstract}
Partial hydatidiform mole can evolve into a metastatic trophoblastic tumor. A 36-year-old, multiparous woman, pregnant with a 22-week embryonic hydatidiform mole, having spontaneously expelled. Histopathological examination showed a non-invasive partial mole. During biological monitoring, a trophoblastic tumor was diagnosed with pulmonary metastasis on CT-scan and myometrial invasion by MRI. Authors opted for a monochemotherapy with a good evolution. The potential risk of malignant transformation of the partial hydatidiform mole requires an adequate therapeutic strategy with strict monitoring.
\end{abstract}

Keywords: 22 weeks amenorrhea, Chemotherapy, Myometrial invasion, Partial hydatidiform mole, Pulmonary metastasis, Trophoblastic tumor

\section{INTRODUCTION}

An embryonated mole corresponds to any partial hydatidiform mole, composed simultaneously of a normal placenta, an amniotic cavity and a recognizable fetal structure. In 80 to $90 \%$ of cases, PHM progresses to spontaneous miscarriage, going unnoticed outside of a systematic anatomopathological study. ${ }^{1}$ The diagnosis is evoked in front of a honeycombed image on ultrasound, associated with a high level of Bhcg, while the confirmation is essentially anatomopathological. Apart from a few sporadic cases, the evolution of PHM remains benign. This work reports the case of a PHM having progressed to a gestational trophoblastic tumor with metastases.

\section{CASE REPORT}

Mrs. K. K., 36 years old, G5P3, without notable pathological history, $\mathrm{O}+\mathrm{ve}$ blood type, who consulted for exaggeration of the sympathetic signs of pregnancy without metrorrhagia on an amenorrhea of 11 weeks. The clinical examination found a patient in good condition with a gynecological examination: a uterine height greater than the theoretical gestational age, with a purplish cervix with no bleeding. The quantitative test of Bhcg showed a rate of $2718700 \mathrm{mIU} / \mathrm{ml}$. Obstetric ultrasound showed a partial molar pregnancy with a fetal biometric of 12 weeks. the evolution was normal until 22 weeks (Figure1) when the patient went into labor naturally and gave birth to a male fetus of $745 \mathrm{~g}$ with a retained placenta, having required an artificial delivery followed by an ultrasound-guided aspiration under sedation (Figure 2).

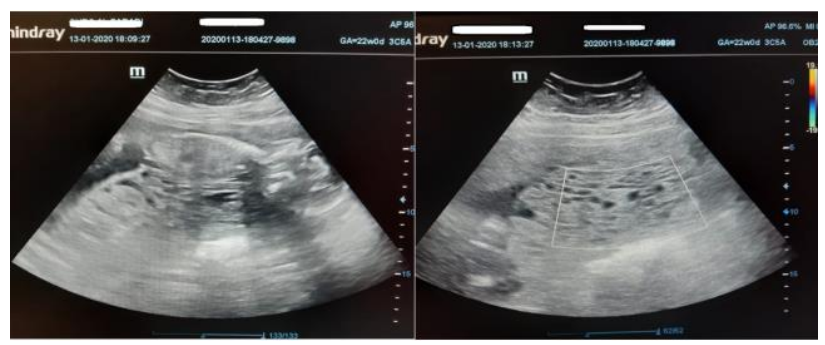

Figure 1: 22-week embryonic hydatidiform mole on pelvic ultrasound. 


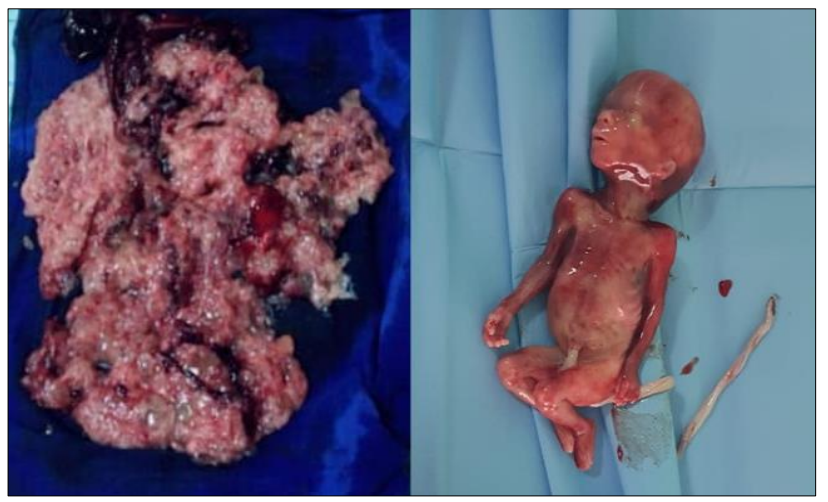

Figure 2: Macroscopic appearance of the partial hydatidiform mole.

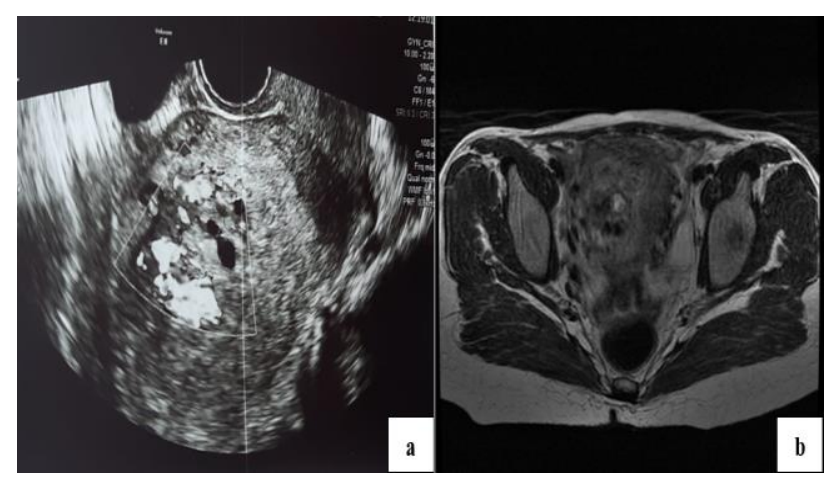

Figure 3: myometrial invasion, a) ultrasound aspect, b) MRI aspect.

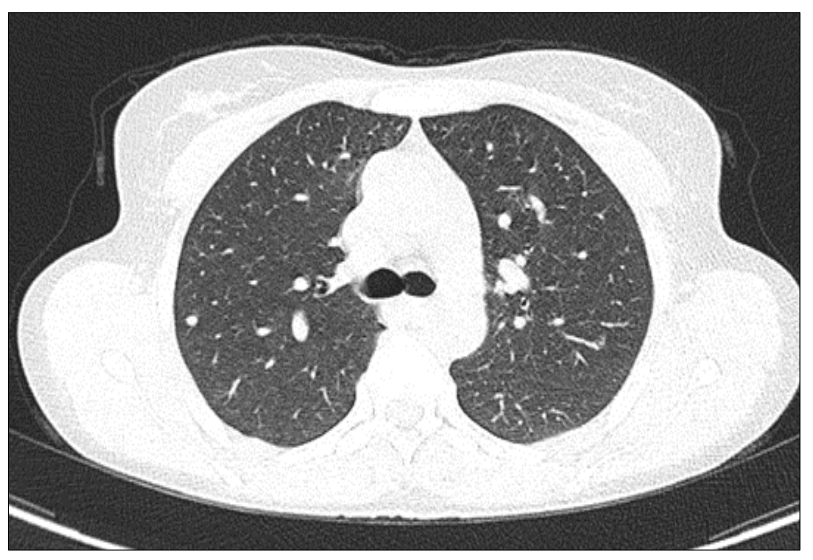

Figure 4: CT-scan: metastatic lung nodule.

A histological examination showed a non-invasive partial hydatidiform mole. Post-aspiration surveillance of Bhcg levels revealed stagnation over 4 successive weeks. The diagnosis of GTT was retained. A regional extension assessment made of a pelvic ultrasound (Figure 3) and MRI was done, having objectified anterior myometrial invasion with vascular areas on ultrasound, associated with a heterogeneous right lateral heterogeneous mass on the right, locally spreading serpiginous vascular structures on MRI. The remote extension assessment showed an abnormality in the supernatural white matter not specific to cerebral MRI, with a pulmonary nodule of the upper right lobe of $4 \mathrm{~mm}$ of metastatic appearance on the thoraco-abdomino-pelvic scan (Figure 4). The FIGO score was less than 6 , the patient was classified as low risk and then referred to the oncology center for monochemotherapy with good tolerance and good progress over a 6-month follow-up.

\section{DISCUSSION}

The partial hydatidiform mole corresponds to a mixture of molar, placental vesicles and a recognizable embryo, caused by chromosomal accidents essentially a triploidy of paternal origin ( $85 \%$ of cases) which comes from the fertilization of a normal ovum by two normal spermatozoons. haploid (dispermia), or by a single diploid spermzoon (diandria). Maternal triploidy found in $15 \%$ of cases results from the fertilization of an abnormal diploid egg by a normal haploid sperm. ${ }^{1}$

Unlike CHM, PHM is more common among young women (peak at 27 years old) with spontaneous abortion history. ${ }^{2,3}$ Except for the clinical presentation of obvious expulsion of molar vesicle with embryo, the diagnosis of PHM is made on an abnormally increased level of Bhcg compared to gestational age (explained by the expression of genes carried by the long arm of the chromosome Paternal 19) involved in hormonal production. ${ }^{4}$ Associated with an ultrasound aspect objectifying a large and heterogeneous placenta, with part of the trophoblast of normal appearance while the other comprises a tissue of different echogenicity, filling most of the cavity and appearance in snowflakes. ${ }^{1,2,5}$ The presence of a gestational sac is mandatory to define an embryonic mole. In the first trimester, PHM lead often to spontaneous abortions, with normal embryos but hypotrophic in two thirds of the cases, or malformed in one third of the cases. ${ }^{6,7}$ The placenta is thick, sometimes with vesicular images. The diagnosis of embryonated mole can be suspected as early as the tenth week of pregnancy. ${ }^{2,8}$ The anatomopathological study is the reference examination to confirm the diagnosis finding a mixture of molar and non-molar villi. ${ }^{9}$ The cytogenetic study confirms the origin of the triploidy as well as the chromosomal play. ${ }^{10}$

The evolution of PHM is favorable in $96 \%$ of cases. Only 2 to $4 \%$ progress to a GTT whereas $0.5 \%$ turns into choriocarcinoma according to a study carried out by $\mathrm{M}$. Seckl. ${ }^{5,11,13}$ This risk of degeneration into a trophoblastic tumor is linked to gestational age during uterine evacuation. ${ }^{14}$ The embryonic molar pregnancy can be complicated by a pregnancy nephropathy related to a pathological trophoblastic colonization also giving cases of pre-eclampsia, in addition to an intra uterine growth retardation found in $93 \%$ of the cases. ${ }^{6,8}$

A biological control by weekly dosing of plasma Bhcg associated with an emptiness ultrasound is essential, and monitoring - after negativation of the Bhcg level on three 
successive weekly dosages - is ensured by the dosing of the Bhcg rate monthly for 6 months under the control of a strict oral contraception is effective. ${ }^{15}$

Clearly, if PHM can develop into a persistent trophoblastic tumor, it is essential to detect it early to avoid very serious complications involving lifethreatening conditions among women of reproductive age. The diagnosis of invasive mole is made when molar villi are suspected in the myometrium on hyper echogenicity or hypervascularization with color doppler, this was the case with our patient, or outside the uterus; and / or when the Bhcg level is abnormally persistent or in ascent after a molar pregnancy with no residual mole in the uterine cavity confirmed by endo-vaginal ultrasound. The seat of the grafted villi is preferably the myometrium, sometimes the vaginal wall, more rarely the peritoneum and the lungs. Their number is limited and their existence is temporary, rarely exceeding 4 months.

The assessment of radiological extension has a place only if the PHM is invasive or it has evolved into GTT. With a chest X-ray for FIGO 2000 score counting necessary for the therapeutic decision between mono or multidrug therapy. Hysterectomy can only be considered if the patient has finished her reproductive plans or refuses regular monitoring.

The risk of recurrence is rare from $0.6 \%$ to $2 \% .^{6,16}$ In the case of PHM, the type of recurrent mole is complete hydatidiform mole in $23 \%$ of cases and PHM in $96 \%$ of cases. $^{12}$

Women's fertility after PHM remains unaffected, except that an early pregnancy can delay the diagnosis of a possible GTT or the indication to start an effective oral contraception from uterine evacuation until 6 months to one year after the normalization of the Bhcg level. ${ }^{6,14}$

\section{CONCLUSION}

Admittedly, the hydatidiform mole remains a benign pathology in most of the cases, with a low risk of malignant transformation threatening the prognosis of fertility or even vital for young women, hence the need for rapid and effective management followed by strict monitoring.

Funding: No funding sources

Conflict of interest: None declared

Ethical approval: Not required

\section{REFERENCES}

1. McFadden DE, Pantzar JT, Langlois J. Parental origin and phenotype of triploidy in spontaneous abortions: predominance of diandry and association with the partial hydatidiform mole. Mod Pathol. 2000;66(6):1807-20.
2. Jauniaux E. Ultrasound diagnosis and follow-up of gestational trophoblastic disease. Ultrasound Obstetr Gynecol: Official J Inter Soci Ultrasound Obstet Gynecol. 1998;11(5):367-77.

3. Genest DR. Partial hydatidiform mole: clinicopathological features, differential diagnosis, ploidy and molecular studies, and gold standards for diagnosis. Inter J Gynecol Pathol. 2001;20:315-22.

4. Lavie I, Rao GG, Castrillon DH, Miller DS, Schorge JO. Duration of human chorionic gonadotropin surveillance for partial hydatidiform moles. Am J Obstet Gynecol. 2005;192(5):1362-4.

5. Flici O. Partial hydatidiform moles in Morocco: epidemiological and clinical study. J Gynécol Obstét Biol Reprod. 1983;12:167-76.

6. Golfier F, Labrousse C, Frappart L, Mathian B, Guastalla JP, Trillet-Lenoir V, et al. Evaluation of treatment relating to gestational trophoblastic tumor registered to the French Trophoblastic Disease Reference Center (TDRC) in Lyon from 1999 to 2005. Gynecol Obstet Fertil. 2007;35(3):205-15.

7. Falkert A, Yildiz A, Seelbach-Goebel B. Partial mole with fetal triploidy as a cause for imminent HELLPsyndrome at 16 weeks of gestation. Arch Gynecol Obstet. 2009;279:423-5.

8. Fine CA, Bundy AL, Berkowitz RS, Boswell SB, Berezin AF, Doubilet PM. Sonographic diagnosis of partial hydatidiform mole. Obstet Gynecol. 1989;73(3 Pt 1):414-8.

9. Medeiros F, Callahan MJ, Elvin JA, Dorfman DM, Berkowitz RS, Quade BJ. Intraplacental choriocarcinoma arising in a second trimester placenta with partial hydatidiform mole. Inter $\mathbf{J}$ Gynecol Pathol. 2008;27(2):247-51.

10. Folkins A, Cruz L, Goldstein DP, Berkowitz RS, Crum C, Kindelberger D. Utility of chromosomal chromogenic in situ hybridization as an alternative to flow cytometry and cytogenetics in the diagnosis of early partial hydatidiform moles: a validation study. J Reprod Med. 2010;55(7-8):275-8.

11. Hancock BW, Nazir K, Everard JE. Persistent gestational trophoblastic neoplasia after partial hydatidiform mole incidence and outcome. J Reprod Med. 2006;51:764-6.

12. Sebire NJ, Fisher RA, Foskett M, Rees H, Seckl MJ, Newlands ES. Risk of recurrent hydatidiform mole and subsequent pregnancy outcome following complete or partial hydatidiform molar pregnancy. An Inter J Obstet Gynaecol. 2003;110(1):22-6.

13. Seckl MJ, Fisher RA, Salerno G, Rees H, Paradinas FJ, Foskett M, et al. Choriocarcinoma and partial hydatidiform môles. Lancet. 2000;356(9223):36-9.

14. Boufettal H, Coullin P, Mahdaoui S, Noun M, Hermas S, Samouh N. Les môles hydatiformes partielles au Maroc: étude épidémiologique et clinique. East Mediter Health J. 2012;18:7.

15. Rice LW, Berkowitz RS, Lage JM, Goldstein DP, Bernstein MR. Persistent gestational trophoblastic tumor after partial hydatidiform mole. Gynecol Oncol. 1990;36(3):358-62. 
16. Boufettal H, Coullin $\mathrm{P}$, Mahdaoui S, Noun $\mathrm{M}$, Hermas S, Samouh N. Complete hydatidiform moles in Morocco: epidemiological and clinical study. J Obstet Gynecol Reprod Biol. 2011;40(5):419-29.
Cite this article as: Elamouri I, Tanouti S, Taheri H, Saadi H, Mimouni A. Partial hydatidiform mole evolving into metastatic trophoblastic tumor: case report. Int J Reprod Contracept Obstet Gynecol 2020;9:1713-6. 